\title{
Business Communication with Corporate Social Responsibility
}

\author{
Yung Ho Suh
}

Advisor of Korean Association for Business Communication, Kyung Hee University, Seoul, Korea

About a decade ago, the U.S. subprime mortgage crisis started with the U.S. recession, and the financial meltdown resulting from these subprime mortgage loans caused a worldwide financial crisis. In 2008, the U.S. government considered granting a bailout to the automobile industry. The Big three-GM, Ford, and Chrysler-requested a $\$ 340$ billion bailout from the government, but the problem is that their CEOs went to Washington D.C. to make their plea arriving in their company private jets. This image, obviously, caused public backlash.

Korea also recently saw a crisis resulting from unethical business practices. In 2011, Busan Savings Bank faced a historical financial corruption case involving illegal lending, accounting fraud, and illegal dividends and resulting in a total loss of about 8 billion USD and catastrophic financial damage to many innocent Korean citizens. These unethical managers and their immoral business practices cause incomparable harm to society, and the trust of the people was shaken. In this kind of situation, would communication make a difference?

Communication is an essential factor for growth and success in business. Communication can connect humans to the value that organization creates. Developing communication skills is critical to the career success of individuals as well as to organizational success (Du-Babcock, 2006; Roebuck, 2001).

Communication is defined as the act or process of using

This is an Open Access article distributed under the terms of the Creative Commons Attribution Non-Commercial License (http://creativecommons.org/licenses/ by-nc/4.0/) which permits unrestricted non-commercial use, distribution, and reproduction in any medium, provided the original work is properly cited. Copyright $\odot 2018$ Korean Association for Business Communication. words, sounds, signs, or behaviors to express or exchange information, ideas, thoughts, feelings, etc. with someone else. It can also be defined as a message given to someone as a letter, telephone call, etc. (Webster). Business communication in academia can be defined as "the scholarly study of the use, adaptation, and creation of languages, symbols, and signs to conduct activities that satisfy human needs and wants" (Reinsch, 1994, 1996).

Business communication includes talking, writing, listening, presenting, and expressing ideas and thoughts especially in areas such as customer relations, public relations, and labor relations. There are several groups to communicate with in the business context: Communication among business stakeholders may include communication between the management and employees, communication with customers, and communication with society. Good communication entails better understanding through expression and strengthens the information delivery among participants.

Our interest now is in the following questions: Why should scholars and researchers in business communication realize the importance of corporate social responsibility (CSR) in their research, and how can we deal with CSR in the areas of business education and teaching?

Earlier business communication research and education mainly studied language use and oral and visual presentation techniques in the business context. The research focus seemed to be more on written communication. Business communication research started from communication skills (basic writing, speaking, vocational training, human sciences such as grammar 
and rhetoric, and the evolution of higher education) (Reinsch, 1996).

There is general agreement on the importance of business communication skills and on the need to include them in the business curriculum. Russ (2008) analyzed the status of business communication courses in universities across the U.S. A total of 505 business communication instructors teaching in 321 U.S. universities returned survey results. According to the research, business departments are the dominant sponsor of business communication courses. Most of the topics covered were classified into two categories: 'written communication' and 'public speaking. Instructors placed a stronger emphasis on teaching writing and speaking skills.

Although an increasing number of people recognize the importance of good communication skills for business, it is necessary to mention that understanding others is also a very important aspect of business communication. We believe that business communication requires more discussion on social responsibility and ethical issues in business. Business communication is also needed to more effectively connect to larger issues (the life of the community, substantive community issues such as organizational effectiveness, economic efficiency, procedural justice, interpersonal conflict, and community ethics) and to adapt to increasingly international issues such as cross-cultural communication (Reinsch, 1996). As discussed earlier, the unethical behaviors of business and its leaders are partly due to the failure of the business schools where managerial techniques are mainly taught and discussed while the issues of ethical and moral education are rarely brought up. From this context, business communication now needs to open a new horizon with communication among stakeholders in business as a central issue.

Management education has so far sought to provide business leaders with techniques that focused on economic growth in the past. Business now must think about social and environmental value as much as its commitment to the financial value of stockholders. The cases mentioned earlier show the moral hazards business leaders have recently witnessed. For sustainable growth and the development of business, these issues must be studied in the area of business communication.

Educational issues on business ethics were also raised by the international community at the United Nations (UN). The UNbacked initiative was launched in 2007 to better prepare current and future organizational leaders for their dual roles as economic developer and social servant. The United Nations Global Compact (UNGC)'s principles provide guidelines to business schools on how to incorporate the concept of responsibility and sustainability in their education, research, and related outreach functions. The initiative of the UNGC is meant to inspire and champion responsible management education, research, and thoughtful leadership around the world.

PRME (Principles for Responsible Management Education) is characterized as the academic side of the UNGC. It is jointly sponsored by the AACSB International (Association to Advance Collegiate Schools of Business), the Aspen Institute, the European Foundation for Management Development, the Globally Responsible Leadership Initiative, and Net Impact. The PRME, now endorsed by over 300 business schools from 62 countries (including four Korean member business schools), serves as a guideline for management education providers to better prepare current and future organizational leaders for a responsible and bright future. Yet with more than 12,000 business degree granting institutions worldwide, this process has just begun.

Founded in 2011, the Korean Association for Business Communication $(\mathrm{KABC})$ has worked closely together with PRME in the area of responsible management education. The main thrust of the $\mathrm{KABC}$ is to foster education and research in the area of socially responsible business communication among business stakeholders such as workers, managers, customers, society, and shareholders. Responsible business communication must foster trust among stakeholders in business in order to maximize mutual understanding and minimize conflict for sustainable growth and development. The following are the KABC's vision and mission statements.

\section{Vision Statements of KABC}

- To systematize business communication studies in order to ensure the sustainable management of businesses and industries

- To contribute to industries and national economic development by spreading ideas

- To contribute to the social benefit and development of business communication through research and international exchange

- To promote friendship among business communication organizations and members

\section{Missions of KABC}

- To research theories and applications regarding business communication

- To organize industry-university collaborative activities for the development of business communication

- To publish and distribute a journal on business communication

- To hold academic conferences and joint symposiums with related organizations/industries 
- To foster the exchange of ideas and activities among national and international academic associations and related institutions that share a common purpose

- To promote study and research and give awards for academic and business achievements

For education and research development, the KABC is looking at methodological perspectives as well on both sides, the technical aspects as well as the domain/theoretical aspects. First, in terms of technical aspects, we are still emphasizing the importance of traditional business communication in order to communicate efficiently and effectively, focusing on oral communication, verbal communication, non-verbal communication, written communication, and presentations. At the same time, the KABC also examines the domain/theoretical aspects of business communication such as interdisciplinary study with an emphasis on CSR in the fields of leadership, public relationships, customer relationships in marketing, labor relationships in personnel management, investor relationships in finance, and ethics in information systems.

\section{References}

Du-Babcock, B. (2006). Teaching business communication: Past, present, and future. Journal of Business Communication, 43(3), 253-264.

John, V. T., \& Courtland, L. B. (2008). Excellence in business communication (8th ed.). London, England: Prentice Hall.

Reinsch, N. L., Jr. (1994, November). Going into business: Toward a research agenda for business communication. Paper (Outstanding Researcher Award Lecture) presented at the 59th Annual Convention of the Association for Business Communication, San Diego, CA.

Reinsch, N. L., Jr. (1996). Business communication: Present, past, and future. Management Communication Quarterly, 10(1), 27-49.

Russ, T. L. (2009). The status of the business communication course at U.S. colleges and universities. Business and Professional Communication Quarterly, 72(4), 395-413.

\section{Yung Ho Suh}

School of Management, Kyung Hee University, 26 Kyungheedae-ro, Dongdaemun-gu, Seoul 02447, Korea Tel: +82-2-961-0780, E-mail: suhy@khu.ac.kr 